\title{
Fenomena Model Kepimimpinan Dalam Memupuk Bakat Wirausaha Pada Karyawan
}

\author{
Futum Hubaib \\ Universitas 17 Agustus 1945,futumhubaib69@gmail.com
}

\begin{abstract}
ABSTRAK
Penelitian ini menelaah tentang pergeseran nilai dari proses transformasi yang sekarang menekan Pendidikan dan pembelajaran tidak hanya menyediakan kapasitas penilaian dan pemahaman, tetapi juga dibimbing untuk membangun sistem proses pembelajaran kewirausahaan. dari dasar ini perlu untuk mewujudkan nilai-nilai sikap yang harus diterapkan dalam membangun Kepemimpinan dalam Pengembangan Bakat Kewirausahaan. masalah dan tuntutan masa depan sangat sensitif terhadap nilai-nilai sosial dan kesejahteraan ekonomi sementara pekerjaan dan sumber daya alam terus menurun. Langkah-langkah yang cermat diperlukan dalam membangun gaya kepemimpinan dalam mengembangkan bahan bakar kewirausahaan. Penelitian pada jenis kualitatif dengan pendekatan studi fenomenologis penulis berlaku untuk mendapatkan hasil penelitian yang cermat, karena pendekatan ini lebih diarahkan pada objek yang diteliti. Input dan inventarisasi data dari hasil pelaksanaan kegiatan lapangan (Wawancara), Dokumentasi dari responden atau informan yang diwawancarai di lapangan saat penelitian berlangsung .
\end{abstract}

Kata Kunci : Kepemimpinan, Manajemen, Bakat, Wirausaha

\begin{abstract}
This study examines the shift in values from the transformation process that is now suppressing Education and learning not only providing assessment capacity and understanding, but also being guided to build a system of entrepreneurial learning processes. from this basis it is necessary to realize attitudinal values that must be applied in building Leadership in Entrepreneurship Talent Development. future problems and demands are very sensitive to social values and economic welfare while employment and natural resources continue to decline. Careful steps are needed in building a leadership style in developing entrepreneurial fuels. Research on qualitative types with the phenomenological study approach of the author applies to get the results of careful research, because this approach is more directed at the object under study. Input and inventory of data from the results of the implementation of field activities (interviews), documentation of respondents or informants interviewed in the field when the research took place
\end{abstract}

Keywords: Management, Leadership, Talent, Entrepreneurship

Naskah diterima: 20 Juli 2019, direvisi: 12 Agustus 2019, diterbitkan: 16 September 2019

ISSN: 2355-0295, e-ISSN: 2549-8932 


\section{PENDAHULUAN}

Realitas perkembangan global untuk masa yang akan datang sangat dibutuhkan nilai perubahan transformasi pemahaman dan pengertian akan pemberdayaan potensi baik sumber daya alam maupun manusia. Melalui kontrol pelaksanaan pembangunan sumberdaya manusia akan terprogram secara umum dalam lingkup proses pendidikan dan pembelajaran baik formal, informal, dan nonformal. Fakta yang terbentuk di lapangan menunjukan kompetensi akan nilai proses gaya kepemimpinan yang mempunyai jiwa kewirausahaan menjadi obyek pembahasan dalam kajian penelitian ini. Hal ini disebabkan kepemimpinan berperan aktif dalam menentukan langkah kebijakan, kewenangan sekaligus pengawasan yang melekat dan diperlukan implementasi gaya kepemimpinan yang akurat cermat dan tepat dalam membangun bakat kewirausahaan.

Gaya kepemimpinan dan kewirausahaan akan terbangun dalam suatu institusi apabila komponen dasar kewirausahaan itu sendiri dilaksanakan secara mendasar. pimpinan harus faham akan nilai dasar kewirausahaan dan mekanisme pembentuknya dalam membangun jiwa dan budaya kewirausahaan yang jelas dan pasti. Kebutuhan perkembangan nilai jiwa kewirausahaan harus dibangun dari mulai sekarang untuk melihat kondisi yang akan datang. Beberapa nilai yang mendasar dari pemahaman pembangunan nilai gaya kepemimpinan saat ini dibutuhkan bentuk implementasi yang membangun kepercayaan, komitmen dan mempengaruhi kemajuan yang konsisten dalam membangun pemahaman dan pemikiran generasi yang akan datang (Avolio, 2007) mengilhami visi bersama, di mana pemimpin membesarkan orang lain dalam berbagi visi bersama dengan melibatkan nilai, minat, harapan dan impian orang tersebut.,sehingga seorang pemimpin bukan hanya mampu menjadi manajer di lembaganya akan tetapi juga punya kemampuan,untuk membangun konsep konsep pemikiran baru bagi staf dan anak buahnya untuk menciptakan suatu system yang saling mendukung.
Kenyataan yang terjadi Visi yang terbangun secara retorika ditetapkan bukan dari hasil bersama akan tetapi dari nilai pembentukan proses yang dilaksanakan sebuah mekanisme kerja organisasi dalam melihat sistem proses yang harus ditetapkan dalam suatu bentuk implementasi kinerja yang akan dilaksanakan atau capaian yang akan dituju. Mengangkat hal dasar tersebut maka komponen dasar kegiatan secara sistematis dari pemahaman avolio (2007) menunjukan nilai Visi merupakan kesepakatan bersama. hal ini menunukan kebersamaan yang paling dasar terbentuk untuk menetapkan visi pelaksanaan bentuk kerja kinerja dan sasaran serta tujuan yang akan dilaksanakan. Umum yang dilihat peneliti dalam keseharian justru visi tersebut telah ditentukan dan semua komponen harus menuju kepada mekanisme yang telah ditetapkan.

\section{Gaya Manajemen Kepemimpinan}

Kepemimpinan adalah proses atau kegiatan untuk mempengaruhi aktifitas seseorang atau kelompok,di dalam upaya untuk mencapai sasaran,yang telah ditetapkan difenisi ini dikemukakan oleh Fuad (lihat,Sulastriningsih,Komalasari\&Handayani, 2018)

Tentang gaya kepemimpinan yang mempunyai jiwa kewirausahaan menjadi pemikiran bagai mana secara mendasar Perumusan Visi yang diterapkan sebagai bentuk Implementasi gaya kepemimpinan untuk membangun pengembangan bakat kewirausahaan. Hal ini sesuai dengan dasar proses pelaksanaan yang membangun nilai sosial ekologi sebagai arah transformasi dalam lingkup pembangunan berkelanjutan, dan sistem pelaksanaan perwujudan pendidikan berkualitas dengan penerapan nilai pelaksanaan pendidikan berkelanjutan. Bakat kewirausahaan merupakan perwujudan nilai potensi pribadi dari setiap individu. Dalam lingkup pemikiran secara lingkungan dengan mengambil contoh lingkungan pendidikan maka dapat dipastikan nilai bakat individu dapat terbangun dan teridentifikasi atas jumlah seluruh komponen sumber daya manusia yang ada di wilayah tersebut. tingkat pemahaman nilai potensi individu akan diukur dengan bentuk sistem nilai yang membangun lingkungan secara lokal untuk 
mengembangkan potensi bakat menjadi kewirausahaan (Apendi. 2018).

Memahami tentang kepemimpinan,pendapat Bahwa nilai Implementasi Gaya Kepemimpinan didefinisikan sebagai bentuk perwujudan sikap, karakter dan mental dari seorang pemimpin dalam menyelesaikan masalah atas dasar pemikiran empiris terstruktur dengan penerapan pemahaman sistematis baik perencanaan, tatakelola, pelaksanaan maupun kontrol yang akan dituangkan dalam bentuk kebijakan dan kewenangan.( Taufik (2017) Kemampuan individu pemimpin teruji secara sistem nilai dan disiplin yang tinggi dengan pemahaman dan pemikiran yang luas. sementara lainnya menetapkan gaya kepemimpinan merupakan peran dalam suatu kegiatan organisasi yang berdasarkan tugas serta fungsi. Kajian telaahan yang mendalam dikemukakan peneliti dalam disertasinya menunjukan pemahaman berbeda antara penerapan implementasi dan peran. Konsep dasar ini yang akan menentukan arah perkembangan kepemimpinan kedepan,

Perwujudan mendasar dari pemahaman implementasi gaya kepemimpinan akan terstruktur mendasar terbangun dari kemampuan diri akan prinsip dasar sistem nilai yang ditunjang implementasi atas dasar keyakinan, sikap, etik, estetik, logik dan Teleleologik. Terbangunnya sikap ini akan membangun komponen secara berkelanjutan dan berkesinambungan. Sementara peran ditetapkan oleh waktu, situasi, kondisi dan keadaan. Hal ini tidak dapat memberikan nilai kesinambungan secara pasti mengingat waktu dan perwujudan yang telah ditetapkan secara mendasar. terkait dengan kewirausahaan yang berkelanjutan nilai implementasi gaya kepemimpinan menjadi penting dalam membangun sikap proses gaya kepemimpinan kewirausahaan yang terbangun, secara mendasar dan membentuk budaya kewirausahaan baik lokal, lingkungan, daerah, nasional, bahkan internasional

\section{KAJIAN LITERATUR Definisi Kepemimpinan}

Menurut Lasry (2010), ada lebih dari 650 definisi kepemimpinan yang dapat ditemukan dalam literatur. Bahkan setelah empat dekade penelitian tentang kepemimpinan, literatur masih dapat dianggap sebagai "rangkaian acara yang membingungkan. Akumulasi data empiris yang tak ada habisnya tidak lagi memiliki pemahaman kepemimpinan yang menyeluruh. " (Lasry, 2010: 32-38). Akan tetapi komponen dasar dalam melaksanakan kegiatan kerja tidak terlepas dadi nilai kepemimpinan dan perwujudan gaya kepemimpinan didalamnya. Berbagai bentuk implementasi gaya dikemukakan dengan lingkup teori sebagai penunjang pemahaman dalam membangun bakat kewirausahaan. perbedaan mendasar antara gaya kepemimpinan umum dan kewirausahaan ditekankan dalam lingkup proses pelaksanaan. Gaya kepemimpinan umum dapat di implementasikan secara mendasar akan proses penerapan teori dasar gaya kepemimpinen dengan penerapan dua, tidak atau bahkan empat gaya sekaligus. Dalam proses pelaksanaan kewirausahaan semua bentuk gaya kepemimpinan harus di kaji dan ditelaah sebagai masukan pemahaman yang jelas akan mekanisme pelaksanaan pembangunan proses dan penempatan potensi tersebut secara individu untuk membangun kegiatan usaha secara mandiri dan. kewirausahaan membentuk Skematik sistem tersendiri dalam implementasi gaya kepemimpinan guna membangun jiwa kewirausahaan yang diharapkan.

Definisi yang paling luas dan disepakati mungkin berasal dari Bennin, salah satu kontributor terpenting dalam studi dan penelitian di bidang kepemimpinan selama lebih dari

enam dekade: "Kepemimpinan adalah fungsi untuk mengetahui diri sendiri, memiliki visi yang dikomunikasikan dengan baik, membangun kepercayaan di antara rekan kerja, dan mengambil tindakan efektif untuk mewujudkan potensi kepemimpinan Anda sendiri "(Bennis, 2007: 02). Dari pemahaman definisi diatas diuraikan secara prinsip pemahaman kepemimpinan berfungsi untuk mengetahui diri, dalam pemahaman tersebut maka sistem nilai (Sanusi, 2012) menjadi acuan pokok dalam implementasi komponen individual yang mendasar. visi yang dikomunikasikan dalam bentuk perwujudan kebersamaan ditetapkan dengan musyawarah 
untuk mencapai sasaran dan target disesuaikan dengan kemampuan dan bakat dasar secara individu dalam membangun kinerja dalam mencapai sasaran dan capaian yang telah ditentukan.

Tindakat efektif menjadi pedoman dalam setiap langkan penetapan kebijakan untuk menjadikan dasar perwujudan implementasi potensi dalam bentuk kepemimpinan secara individu. Hal pernyataan diatas secara landasan teori sangat relevan dengan konsep pengembangan kewirausahaan dari bentuk perwujudan implementasi gaya kepemimpinan yang dilaksanakan. Tidak dipungkiri bahwa gaya kepemimpinan dapat menumbuhkan kemampuan dan kapasitas kepemimpinan secara individu untuk membangun kemampuan orang lain melalui dorongan dari refleksi diri, komunikasi dan kepercayaan di lingkungan sumber daya terbatas sehingga mampu mendorong staf/karyawan mempunyai keahlian atau profesional di bidang kemampuan dan bakatnya masing masing

\section{METODE PENELITIAN}

Penelitian ini dengan menerapkan pola pendekatan kualitatif dengan model pendekatan study fenomenologi,adalah sebuah pendekatan yang mencoba mendalami makna sebuah konsep fenomena di masyarakat ,serta pengalaman pengalaman yang berlandaskan pengalaman/kajian individu atau personal,dari fenomena dan pengalaman ini kemudian di kaji dan di teliti,kemudian menjadi sebuah kesimpulan,yang bisa bersifat sementara atau dengan waktu yang lama,karena sebuah penelitian apapun itu bentuknya ,adalah sebuah hasil sementara pada saat itu,bisa saja terjadi 'antitesis', dengan hasil penelitian selanjutnya dan ini merupakan khasanah dalam ilmu pengetahuan yang menandakan dunia keilmuan itu tidak stagnan dan selalu berkembang dari jaman ke jaman(Ridwan, 2008)

Dengan komponen dasar penelitian yang ditetapkan melalui proses observasi, wawancara, dokumentasi serta hasil wawancara untuk selanjutnya di olah secara sistematis dengan semua komponen bahasan,adapun penulis dalam mengambil informan dengan menggunakan', sampling terbatas" yang diolah baik secara pendahuluan, landasan teori, hasil penelitian serta ,analisis dengan mereduksi data,penyajian data,kemudian menarik kesimpulan, guna mendapatkan simpulan yang terfokus terhadap komponen yang diteliti yaitu objek pimpinan dan empat orang staf/karyawan yang bekerja pada Lembaga Penjamin Mutu Kalimantan Timur(LPMP) tersebut dengan masa kerja rata rata 5-10 tahun,penulis sengaja mengambil responden/informan yang yang sudah cukup lama bekerja dan mengikuti gaya atau kepemimpinan seorang pimpinan yang bekerja di lembaga tersebut .

Terkait penelitian yang dilaksanakan hasil wawancara dengan para informan atau partisipan di lingkungan lembaga menyatakan kepemimpinan dan manajemen sangat dibutuhkan di lembaga pendidikan, dengan dinyalakan pemahaman yang tinggi. pertanyaan tentang keefektifan kepemimpinan untuk program perubahan, pertimbangan gaya kepemimpinan memungkinkan serangkaian konsep dalam membentuk proses identifikasi dan konsep-konsep dasar yang relevan dengan pedagogi yang berkembang saat ini. Secara kebutuhan untuk eksplorasi gaya kepemimpinan dapat memfasilitasi dengan pengembangan keterampilan dan pemikiran konseptual. Pengembangan gagasan merupakan tanggung jawab pribadi dalam perwujudan gaya kepemimpinan yang diterapkan. Hal ini menyangkut kompetensi dan konsekuensi sebagai pemimpin di lembaga pendidikan dalam mencapai tujuan utama dalam mencapai sasaran dan membangun kepercayaan dalam hal ini di masyarakat dan para pemangku kebijakan.

\section{Analisis Data Penelitian}

Setelah penulis melakukan observasi dan wawancara pada informan tentang manajemen kepeminpinan di kantor LPMP Kalimantan Timur tersebut,memang sangat beragam hasil dari wanacara penulis,akan tetapi dapat kita telaah dari hasil wawancara tersebut semuanya hampir sama pendapatnya,tenatng model kepemimpinan yang lebih berkesan dan mampu merubah pola fikir mereka yang 
tadinya hanya sebagai staf/karyawan biasa,karena ada bakat dan talenta yang mereka miliki,mampu berkehidupan yang lebih dari teman teman mereka.

Terkait dengan wawancara dengan responden/informan yang secara disiplin menguasai komponen dasar pembangunan jiwa kewirausahaan dikemukakan bahwa dukungan gaya kepemimpinan dalam kegiatan kewirausahaan sangat dibutuhkan dan akan menunjang pembangunan potensi diri dan optimalisasi bakat minat dan Ketrampilan. Pembangunan gaya kepemimpinan tidak terfokus dalam menentukan kewenangan dan kebijakan akan tetapi bagaimana membangun untuk memperluas dan bertukar gagasan yang mengarah pada adaptasi praktik terbaik dalam Pembelajaran. Interaksi ini harus terbangun dengan interaksi secara lingkungan (informal), Pendidikan (Formal) dan peningkatan Keterampilan (Non formal). Diharapkan akan terbentuk temuan ilmiah akan potensi bakat melalui interaksi yang melibatkan diantara karyawan, mentor, orang tua, dan Tenaga ahli. Tujuan ini ditopang oleh kepercayaan bahwa sekitar $80 \%$ pengetahuan dan komunikasi kan dengan langkah yang terbaik serta dilakukan melalui jaringan dengan pengembangan manfaat lebih lanjut dari masyarakat yang bekerja sama dan hal ini bukanlah sebuah langkah yang mudah dimana pimpinan biasanya bekerja dalam lingkungan institusi nya sendiri.

Penulis melihat dalam beberapa kali terjun ke lokasi penelitian tentang adanya keinginan staf dan karyawan untuk berbenah diri ,tentu hal ini tidak mudah karena pimpinan yang mempunyai jiwa manajerial dalam mengembangkan bakat wira usaha para staf dan karyawan itu ,memang menjadi sebuah fenomena dan harapan mereka.

Akan tetapi dengan adanya pola kepemimpinan yang sekarang dengan memakai gaya tranformasional,sehingga pimpinan di lembaga tersebut cukup mampu dalam dalam membina bakat dan talenta yang di miliki oleh staf dan karyawannya,sehingga sudah terlihat dari beberapa staf dan karyawan yang cukup'sukses',dibidangnya selain menjadi staf sebagai pekerjaan utama mereka.

\section{PEMBAHASAN}

Dari hasil olah data yang penulis lakukan dari empat orang staf dan karyawan dan satu pimpinan ,dengan langkah-langkah :

a) Melakukan wawancara langsung kepada partisipan/informan.

b) Melakukan kunjungan baik ke tempat lokasi/kerumah partisipan/informan

c) Melakukan interview pada staf yang lain(di luar informan), sebagai pembanding.

d) Melakukan wawancara ulang sebelum olah data.

Adapun hasil dari dialog/wawancara tersebut kami catat dan rekam dan tentunya masih tercampur dengan bahasa daerah setempat,sehingga penulis membuat definisi ulang sesuai dengan narasi yang bisa di mengerti oleh orang lain secara universal(bahasa baku),inilah beberapa petikan hasil dialog/wawancara tersebut ,berupa teks ,sesuai dengan kode etik informan maka dengan kesepakatan kedua fihak (antara penulis\&informan),hanya menggunakan inisial sebagai nama informan : Informan (1).

Nama : ST

Umur : 35 Tahun

Status : Staf Bagian perlengkapan.

Pendapat : Sebagai seorang staf pada kantor Pemerintah,saya cukup mempunyai waktu luang pada hari Sabtu dan Minggu,waktu tersebut saya gunakan untuk usaha ternak ayam buras,dan sudah berjalan beberapa tahun.Saya termotivasi dari pimpinan yang selalu memberikan arahan tentang pentingnya menambah penghasilan (luaran) namun tidak meninggalkan tugas utama (hasil wawancara ,tanggal 22 Februari 2019).

Informan (2)

Nama : MD

Umur : 41 Tahun

Status : Staf bagian TU

Pendapat: Saya sudah bekerja 8 tahun, dan punya keluarga,itulah yang memicu saya untuk ber wira usaha,dengan berjualan makanan membantu ,(usaha sampingan istri),dan hasilnya cukup lumayan motivasi dan masukan dari pimpinan setiap ada rapat,sehingga saya mencobanya serta yyang lebih penting tidak mengganggu pekerjaan rutin saya karena kami bergantian waktu 
melayani pelanggan wawancara,tanggal 22 Februari 2019)

Informan(3)

Nama

: BS

Umur

: 29 tahun

Status : Staf Bagian.TU.

Pendapat: Saya sudah bekerja sekitar lima tahun dan juga sudah berkeluarga,saya mendukung program pimpinan yang memberikan arahan tentang wira usaha,kebetulan saya ada ketrampilan elektro,sepulang kerja saya menekuni usaha saya bidang jasa perbaikan alat alat listrik,saya dengan dua karyawan,dan hasilnya cukup untuk tambahan gaji saya sebagai pegawai.(hasil wawancara,tanggal 24 Februari 2019)

Informan(4)

Nama : WL

Umur : 48 Tahun

Status : Staf bagian umum.

Pendapat : Saya mendapat motivasi dari pimpinan tentang wira usaha, dan saya coba untuk membina anak saya,karena ia punya bakat jualan, dan depan rumah saya jadikan warung sembako, dan sekarang sudah lumayan berkembang dari hasil usaha tersebut. (hasil wawancara tanggal 24 Feruari 2019)

Informan(5)

Nama : AS

Umur : 51(tahun)

Status : Pimpinan bagian (Kabag)

Pendapat : Tujuan saya memotivasi staf staf saya,untuk memuat waktu yang lowong dapat menjadi penghasilan,sehingga di setiap pertemuan/rapat saya ,selalu memberikan motivasi ,karena saya sendiri dengan perlahan membangun rumah sewa/kost, kemudian dibawahnya saya buat warung makan,dan saya melihat beberapa staf itu punya bakat yang bila dikembangkan dapat menjadikan sebuah penghasil,tanpa mengganggu pekerjaan utama mereka.(hasil wawancara tanggal 24 Februari 2019)

Dari hasil wawancara diatas dapat kita lihat bahwasanya pemimpin yang mampu membangkitkan semangat baik berkarir di lembaganya sendiri ataupun punya bakat wirausaha,akan menjadi semacam fenomena yang menarik,dan para karyawan .staf juga akan termotivasi dalam peningkatan kehidupan mereka.

Model kepemimpinan dan manajemen dirangkum oleh Crawford (2009), yang berkaitan dengan karakteristik pribadi dari teori kontekstual gaya kepemimpinan, akan teori transaksional atau transformatif yang diterapkan secara umum. Sementara Konsep kepemimpinan pendidikan Darwin, menurut lnbar (2009), menegaskan bahwa kepemimpinan pendidikan muncul secara bertahap sebagai "orang yang selamat dari sebuah sistem," yaitu mereka yang telah berhasil menaiki tangga hierarkis, yang dianggap mampu memimpin, mampu mengembangkan kapasitas organisasi.

Konsep dasar pemahaman manajemen kepemimpinan secara mekanisme adalah membentuk kebersamaan untuk mewujudkan nilai positif dalam lingkungan kerja dan membentuk kinerja yang sesuai dengan capaian dan tujuan yang telah ditetapkan. Dari hal tersebut maka memajukan pengetahuan tentang pengembangan gaya kepemimpinan. James dkk, (2007), dalam mengembangkan gagasan ini, mengemukakan bahwa kepemimpinan adalah cara orang mengubah pikiran orang lain dan memindahkan organisasi ke depan untuk mencapai tujuan yang teridentifikasi.

Komponen utama yang menjadi tujuan program pendidikan dalam pembangunan sumber daya manusia atas mekanisme pemahaman gaya kepemimpinan diarahkan untuk membina kepemimpinan adalah menciptakan kondisi yang memungkinkan dan mendorong tindakan kepemimpinan. Jenis dan model kepemimpinan Matveev dan Lvina (2007), menyatakan bahwa kepemimpinan organisasi telah berkembang sebagai sifat perilaku.

Secara pembahasan umum ada tiga teori manajemen kepemimpinan yang paling banyak dikenal dalam sudut pandang ini adalah teori kepemimpinan karismatik, teori strategis kepemimpinan karismatik, dan teori kepemimpinan penuh. Mereka selanjutnya memberi dua sub kategori kepemimpinan dalam jenis ini - transfonnasi nal dan 
transaksional. Pemimpin transaksional adalah pemimpin yang menggunakan penghargaan kontingen sebagai penguatan positif ketika standar yang diinginkan tercapai atau manajemen oleh pengecualian sebagai hukuman atau umpan balik negatif setelah terjadi masalah. Pemimpin transformasional, pada gilirannya, mampu memengaruhi pengikut mereka untuk mengatasi kepentingan pribadi dan menggunakan potensi penuh mereka untuk mencapai tujuan organisasi mereka (Bass dan Riggio, 2006 and Nonhouse, 2013).

Penelitian yang terstruktur membangun implementasi data yang spesifik. Dari kegiatan penelitian yang paling menonjol di antara ini adalah Leithwood yang bersama rekan-rekannya menyelidiki kepemimpinan transformasional sepanjang akhir 1980an dan awal 1990an. Berdasarkan temuan penelitian kuantitatif dan kualitatif, mereka mengemukakan model kepemimpinan transformasional yang mencakup tiga kategori utama praktik kepemimpinan: menetapkan arahan, mengembangkan orang dan merancang ulang organisasi (Leithwood et al, 2006).

Pemahaman mendasar dapat dilihat dari implementasi penerapan visi. Visi adalah pesan, disampaikan melalui semacam 'simbolisme' dan inilah pesan yang menyatukan pemimpin pendidikan dan pengikutnya dalam usaha bersama untuk mewujudkannya. Banyak model pedagogis mencirikan pemimpin sebagai orang yang menginspirasi para pengikutnya (StrauchNelson, 2012). Mereka selanjutnya mengaitkan keyakinan pemimpin pendidikan dengan kekuatan pribadi pemimpin; kekuatan yang memungkinkan pemimpin untuk meningkatkan komitmen pengikut dan rasa signifikasi melalui kontribusi pribadi mereka di taman kanak-kanak. Dengan kemampuannya untuk berkomunikasi, dan juga dengan memimpin di contohkan bahwa seorang pemimpin pendidikan di lembaga pendidikan mengekspresikan harapan tinggi para pengikut dan kemampuan mereka untuk mewujudkan visi pemimpin.
Secara mendasar komponen utama dalam Manajemen gaya kepemimpinan dalam pengembangan bakat kewirausahaan diterapkan nilai kebersamaan, persamaan disiplin dan pengetahuan serta komunikasi yang tepat dan cermat. Teori pedagogis yang bersumber gagasan dan inspirasi dalam penelitian, ditemukan dalam karya Montessori (1907, dikutip dalam Lillard, 2005) dan Froebel (1889, dikutip dalam Strauch-Nelson, 2012), yang memeriksa dan menjelaskan konsep 'pedagogi alami', baik di dalam maupun di luar lingkungan pendidikan, memanfaatkan wawasan dari alam. Argumennya menunjukkan bahwa dengan mendorong mereka untuk mencintai alam, individu lebih cenderung untuk merawat alam, karena kita menghargai hal-hal yang kita cintai.

Namun, aspek yang lebih penting dari pekerjaan ini adalah dorongan individu untuk memusatkan perhatian mereka melalui model kognitif di dalam lingkungan alam mereka. Pendekatan ini, dengan sendirinya, tidak cukup untuk generasi muda, jadi guru telah mempersiapkan untuk melengkapi pelatihan ini dengan pertimbangan, simpati dan cinta sebagai elemen penting yang membantu setiap individu terhubung dengan dirinya dan lingkungannya. Dipertahankan bahwa bersama-sama, teori-teori ini berdampak pada generasi mendatang dengan proyeksi enam dimensi kunci: keyakinan, keterampilan sosial, bahasa dan komunikasi, motivasi dan konsentrasi, keterampilan fisik dan pemahaman. berdasarkan interaksi mereka dengan alam, dapat berkembang di dalam diri generasi muda untuk memiliki rasa, memiliki hal pemahaman yang baru yang merupakan hasil dari pengalaman alam yang membentuk kebersamaan dan kesetaraan (Strauch-Nelson , 2012).

\section{PENUTUP}

Intinya pimpinan yang ideal itu adalah seorang pimpinan yang mampu memerikan motivasi bukan hanya pada bidang pekerjaan yang ada di lembaganya ,namun harus mampu melihat setiap bakat/kelebihan anak buahnya,kemudian memberikan motivasi ,sehingga mampu menciptakan hasil 
Pada bidang yang mereka kuasai

Penelitian ini sifatnya hasil telaah dipersilahkan pada peneliti lainnya untuk ,melanjutkan dalam model pendekatan lainnya,karena sifatnya penelitian adalah semakin di perdalam akan menemukan hal hal yang sifatnya 'kebaruan'”untuk perkembangan ilmu pengetahuan dimasa kini dan akan datang.

Wirausaha terbentuk dari lingkup dasar kepemimpinan secara individu pengembangan bakat kewirausahaan merupakan bentuk upaya proses pembelajaran yang membangun kemandirian dalam wira usaha. Implementasi gaya kepemimpinan merupakan penerapan memikirkan sistematis yang terstruktur atas dasar penelaahan empiris, perencanaan, tatakelola, pelaksanaan dan Kontrol.

Dalam membangun bakat kewirausahaan dibangun kesetaraan dan kebersamaan dalam membangun keyakinan, keterampilan sosial, bahasa dan komunikasi, motivasi dan konsentrasi, keterampilan fisik dan pemahaman. berdasarkan interaksi mereka dengan alam, dapat berkembang di dalam diri generasi muda hal ini secara lingkup mendasar dapat membangun kepercayaan dan keyakinan dalam menetapkan langkah kedepan yang positif.

\section{REFERENSI}

Apendi, Tatang. (2018). Manajemen Pembelajaran Kewirausahaan dalam Membentuk Kemandirian Mahasiswa di Perguruan Tinggi Swasta. Sinopsis Disertasi., Univ Islam Nusantara (UNINUS), Januari 2018.

Avolio, B.J. (2007) Full range leadership. development. (2nd ed). London: Sage Bass, B.M. and Riggio, R.E. (2006). Transformational Leadership. (2nd) Mahwah, NJ: Lawrence Erlbaum.

Bennis, W. (2007) 'The Challenges of Leadership in the Modern World: IntroductionSpecial Issue' American Psychologi to the st, Vol: 62 (1), 2-5.
Inbar, D. (2009) 'Educational Leadership in. an Age of Contradictions', Hod Hachinuch, Vol: 83 (4), 52-54) leadership learning for school leaders', Management Learning, Vol: 38 (1),79 94. doi: 10.1177/1350507607073026.

James, K.T. Mann, J. and Creasy, J. (2007) ‘ . Leaders as lead learners - A case example of facilitating collaborative Lasry, D. (2010) 'From Survival to Creativity', Hod Hagan: Histadrut Hamoriem, Vol: 74 (3), 3238 .

Leithwood, K. Day, C. Sammons, P. Hopkins, D. and Harris, A(2006) Successful school leadership: What is it and how it influences pupil learning. A report the Department for Education http://webarchive.nationalarchives gov.uk/publications.

Matveev and Lvina, (2007) The perception of intercultural communication competence by American and Russian managers with experience on multicultural teams. Dissertation : Ohio University. Ann Arbor, MI: UMI Dissertation Services.

Northouse, P.G. (2013) Leadership: theory. and practice. (6th ed). London: Sage StrauchNelson, W. (2012) 'Transplanting Froebel into the present', International Journal of Education through Art,vol 8(1), 59-72. doi: 10.1386/eta.8.1.59_1.

R. Dewi Sulastriningsih, Yunika Komalasari \&Rina Dwi Handayani(2018), Beban Kerja Dan Kepemimpinan Tranformasional Implikasinya Pada Kepuasan Kerja Karyawan, Jurnal Ecodemica.vol (2) No.2,Sept 2018,156-157, DOI: http://ejournal.bsi.ac.id/ejurnal/index.php/eco demica/article/view/2945.

Taufik, Ali (2017). Implementasi gaya Kepemimpinan Transformasional dan Transaksional. Sinopsis Disertasi ( 2017). Islam Univ Nusantara (UNINUS) 2017. 


\section{BIODATA PENULIS}

Futum Hubaib, Dosen pada Universitas 17

Agustus 1945 Samarinda ,Doktor Manajemen

Ekonomi. 